\title{
The influence of dietary intake and meal pattern on blood glucose control in children and adolescents using intensive insulin treatment
}

\author{
N. C. Øverby • H. D. Margeirsdottir • C. Brunborg • \\ L. F. Andersen $\cdot$ K. Dahl-Jørgensen
}

Received: 23 March 2007 / Accepted: 29 June 2007 / Published online: 9 August 2007

(C) Springer-Verlag 2007

\begin{abstract}
Aims/hypothesis We studied dietary factors and their association with blood glucose control in type 1 diabetic children and adolescents using intensive insulin treatment. Materials and methods $\mathrm{A}$ total of 550 children and adolescents with type 1 diabetes mellitus (age 2-19 years) recorded their diet for 4 days in pre-coded food diaries. Of the study group, $34 \%$ used insulin pumps, $43 \%$ used four or more injections and $16 \%$ three injections per day. $\mathrm{HbA}_{1 \mathrm{c}}$ was related to targets of optimal blood glucose control defined by the International Society for Pediatric and Adolescent Diabetes (ISPAD).

Results Adolescents with optimal glucose control $\left(\mathrm{HbA}_{1 \mathrm{c}}\right.$ $\leq 7.5 \%$ ) had a lower intake of added sugar ( 7.7 vs $9.1 \%$ of energy intake, $p=0.004)$, a higher intake of fibre $(19.3 \mathrm{vs}$ $17.0 \mathrm{~g} /$ day, $p=0.01)$ and a higher intake of fruits and vegetables ( 257 vs $227 \mathrm{~g} /$ day, $p=0.04$ ) than those with suboptimal metabolic control $\left(\mathrm{HbA}_{1 \mathrm{c}}>7.5 \%\right)$. Multiple
\end{abstract}

N. C. Øverby $(\bowtie) \cdot$ L. F. Andersen

Department of Nutrition, Institute of Basic Medical Sciences,

Faculty of Medicine, University of Oslo,

$\mathrm{Pb} 1046$ Blindern,

0316 Oslo, Norway

e-mail: ninaco@medisin.uio.no

H. D. Margeirsdottir · K. Dahl-Jørgensen

Department of Pediatrics, Ullevaal University Hospital,

University of Oslo,

Oslo, Norway

C. Brunborg

Center for Clinical Research, Ullevaal University Hospital,

Oslo, Norway

K. Dahl-Jørgensen

Faculty of Medicine, University of Oslo,

Oslo, Norway regression analysis in adolescents showed that fibre and meal pattern were significantly associated with blood glucose control (effect fibre intake $=-0.02, p=0.04$, effect having breakfast regularly $=-0.89, p=0.009$ ). In children meal pattern was associated with blood glucose control (effect having dinner regularly $=-0.66, p=0.02$, effect having supper regularly $=-0.78, p=0.03$ ).

Conclusions/interpretation In diabetic adolescents both intake of fibre and having a regular meal pattern are associated with blood glucose control. Lower intake of added sugar and sugar-sweetened soft drinks and higher intake of fruits and vegetables are observed among those with optimal compared with those with suboptimal blood glucose control. Dietary guidance should be intensified during adolescence to improve dietary intake and blood glucose control.

Keywords Added sugar · Adolescents · Blood glucose control $\cdot$ Child $\cdot$ Diet $\cdot$ Fibre $\cdot \mathrm{HbA}_{1 \mathrm{c}} \cdot$ Intensive insulin treatment $\cdot$ Meal pattern $\cdot$ Type 1 diabetes

\section{Abbreviation \\ NCDQ The Norwegian Childhood Diabetes and Quality project}

\section{Introduction}

Poor blood glucose control is frequently reported in diabetic children and adolescents [1-5]. Several studies have explored predictors of blood glucose control [2, 6-9], and several factors have been identified, e.g. age [2], insulin dosage [7,8], diabetes duration [7] and number of clinical visits $[8,9]$. However, few studies have looked in detail at 
dietary intake and its effects on blood glucose control in children and adolescents $[1,4,10,11]$; moreover, those that have done so had small sample sizes $[1,4,11]$.

A more flexible meal pattern is possible in parallel with the introduction of more intensified insulin regimens. At the same time, dietary recommendations for children and adolescents have changed considerably since the 1980s. Recommendations now favour the intake of more carbohydrate and less protein and fat [12]. The intake of carbohydrate is recommended to consist of whole grain foods, fruits and vegetables, with no more than $10 \%$ of energy intake from added sugar [12]. Furthermore diabetic patients are recommended to eat a high fibre diet to facilitate control of blood glucose [12]. Several studies have demonstrated that intensive insulin treatment both delays the onset and slows the progression of microvascular [13-16] and macrovascular complications $[16,17]$. Thus, addressing and outlining risk factors for poor blood glucose control might have a large impact on diabetes-related complications. Our hypothesis was that a high intake of fibre, low intake of added sugar and a regular meal pattern would all help improve $\mathrm{HbA}_{1 \mathrm{c}}$ in children and adolescents with type 1 diabetes.

\section{Materials and methods}

Participants The participants were recruited from participants in the Norwegian Childhood Diabetes and Quality project (NCDQ) [18]. This is a prospective populationbased study for research and quality improvement by means of benchmarking, and includes all children and adolescents with type 1 diabetes mellitus in Norway, taken from 24 of 25 Norwegian Paediatric Departments. The classification of type 1 diabetes mellitus is made by measurements of autoantibodies (insulin, GAD, protein tyrosine phosphatase) and C-peptide at diagnosis. Children with type 2 diabetes mellitus were not included.

Participants were recruited in 2004 and 2005. The number of NCDQ project participants in 2004 and 2005 was 1,417 and 1,655 respectively. The total number of participants over these 2 years was 1935. Of these, 658 children and adolescents recorded their diet for 4 days, 457 in 2004 and 201 in 2005 . This gives a participation rate of $34 \%$. Three participants were excluded because they participated both years (2005 data excluded). For 550 of the 655 participants, data were available on centralised measurement of $\mathrm{HbA}_{1 \mathrm{c}}$ from the NCDQ project for the year they recorded their diet. This was therefore the number included in the present analyses.

The dietary data collection was carried out from January to April 2004 and 2005 and is described in detail elsewhere [19]. Written information and food diaries were sent to the participants and they were told to record their diet for three specific weekdays and one specific weekend day. All participants were either asked to start recording on the next Sunday or Wednesday. On the second day of recording they were phoned by a nutritionist to encourage them to finish the study. The time for the dietary study was chosen to coincide as closely as possible with the time of yearly visit for NCDQ project. The median time difference from the clinical visit to the time when recording started was 2 weeks. Ninety per cent of the participants recorded their diet within 2 weeks before or 2 weeks after the clinical visit and $\mathrm{HbA}_{1 \mathrm{c}}$ measurement.

The study protocols were approved by the National Committee for Research Ethics in Norway and the Norwegian Social Science Data Services. Informed consent was obtained from the parents and from the participants who were older than 12 years of age.

Questionnaires Participants filled in a questionnaire, which included questions on meal frequency (missing values $=5 \%$ ) and parents' education (missing values $=14 \%$ ) (for further details see [20]). The meal frequency variable was recoded, and having breakfast, dinner and supper regularly was defined as having the meal more than five times a week. Information on BMI (missing=1\%), insulin dose per $\mathrm{kg}$ body weight (missing values $=30 \%$ ), diabetes duration (missing values= $12 \%$ ), insulin regimen (missing values $=6 \%$ ) was obtained from the case record forms used in the NCDQ project. To estimate the prevalence of overweight, the international cutoff points for BMI $\left(\mathrm{kg} / \mathrm{m}^{2}\right)$ for overweight were used [21]. Intensive insulin treatment was defined as using an insulin pump or needing three or more injections per day, but some patients may have used one to two injections per day during the early phase of the disease (remission period).

$H b A_{1 c}$ We determined $\mathrm{HbA}_{1 \mathrm{c}}$ by an HPLC method (Variant; BioRad, Richmond, CA, USA) standardised in line with The Diabetes Control and Complication Trial recommendations [22]. All samples were sent to the same central laboratory at Aker University Hospital, Oslo. Normal reference was 4.1\% to $6.4 \%$ (2 SD) and intra-assay $\mathrm{CV}$ was $<3 \%$. Optimal blood glucose control was defined as having $\mathrm{HbA}_{1 \mathrm{c}} \leq 7.5 \%$ and suboptimal control as having $\mathrm{HbA}_{1 \mathrm{c}}>7.5 \%$. These targets of optimal blood glucose control have been defined by the International Society for Pediatric and Adolescent Diabetes (ISPAD) [23] to reduce the risk of cardiovascular disease and microvascular complications.

Food diary The participants recorded their food intake for four consecutive days, in food diaries. The diary has lists of 277 drinks, food items and dishes grouped together according to a typical Norwegian diet. Food amounts are presented in predefined household units or as portions estimated from pictures in a photographic booklet [24] (for further details see [19]). The food diary and the photo- 
graphic booklet have been validated [24-26]. Validation of the food diary among 9-year-olds showed that there were no significant differences in energy intakes on different recording days. However, when comparing under-reporters and actual reporters, under-reporters had a significantly lower energy intake for the last 2 days of the recording period than did actual reporters [26].

Calculations of dietary intake The data entry was made by scanning, using Teleform program 6.0 and 8.1 (Datascan, Oslo, Norway). Daily intake of foods, energy and nutrients were computed using a food database and software system developed at the Department of Nutrition, University of Oslo (for further details see [19]). When the term added sugar is used it refers to refined or industrially produced sugar (not including naturally occurring mono- and disaccharides) used as an ingredient in processed or prepared food. Furthermore, day-to-day variation in nutrient intake is presented and expressed as the $\mathrm{CV}(\mathrm{CV}=\mathrm{SD} \times 100 /$ mean $)$ [27].

Statistical analysis Demographic and clinical data and nutrient intakes are presented as means with SDs for those with optimal and suboptimal blood glucose control (Table 1). The data for all analyses are separated into two age groups: children (2-10 years old) and adolescents (1119 years old). This grouping was chosen to separate the pubertal from the pre-pubertal participants. Ninety-three per cent of the children were at stage 1 in Tanner's puberty score, while eight children were at stage 2 and one at stage 3. Intake of foods and drinks is presented as medians with first and third quartile (Q1, Q3). When comparing continuous variables Student's $t$ test was used for normally distributed data and Mann-Whitney $U$ test for not normally distributed data. The $\chi^{2}$ test was used to compare different $\mathrm{HbA}_{1 \mathrm{c}}$ groups regarding overweight, insulin regimen, parents' education and meal frequencies. Simple and multiple linear regression analyses were used to study possible factors associated with $\mathrm{HbA}_{1 \mathrm{c}}$. All macronutrients, relevant clinical variables and puberty, and diabetes duration were tested in the unadjusted analysis, while only variables with $p<0.1$ were presented and included in the multivariate analysis. Sex and mothers' education were included even when $p>0.1$, only for adjustment in the multivariate analysis. Data on insulin

Table 1 Characteristics of participants

\begin{tabular}{|c|c|c|c|c|c|c|c|}
\hline & \multirow[t]{2}{*}{$\begin{array}{l}\text { All patients } \\
(n=550)\end{array}$} & \multicolumn{3}{|c|}{$\begin{array}{l}\text { 2- to } 10 \text {-year-olds according } \\
\text { to } \mathrm{HbA}_{1 \mathrm{c}}\end{array}$} & \multicolumn{3}{|c|}{$\begin{array}{l}\text { 11- to } 19 \text {-year-olds according } \\
\text { to } \mathrm{HbA}_{1 \mathrm{c}}\end{array}$} \\
\hline & & $\begin{array}{l}\leq 7.5 \% \\
(n=105)\end{array}$ & $\begin{array}{l}>7.5 \% \\
(n=98)\end{array}$ & $p$ value & $\begin{array}{l}\leq 7.5 \% \\
(n=121)\end{array}$ & $\begin{array}{l}>7.5 \% \\
(n=226)\end{array}$ & $p$ value \\
\hline Age (years) ${ }^{\mathrm{a}}$ & $11.3(3.4)$ & $7.7(2.0)$ & $7.6(2.2)$ & 0.92 & $13.3(1.9)$ & $13.6(1.9)$ & 0.15 \\
\hline Male sex $(\%)^{\mathrm{b}}$ & 48.2 & 44.8 & 43.9 & 0.90 & 57.0 & 46.9 & 0.07 \\
\hline Diabetes duration (years) ${ }^{\mathrm{a}}$ & $3.8(3.1)$ & $2.5(2.0)$ & $2.4(1.9)$ & 0.87 & $3.4(3.5)$ & $5.2(3.2)$ & $<0.001$ \\
\hline Puberty stage (Tanner) ${ }^{\mathrm{a}}$ & $2.5(1.6)$ & $1.1(0.5)$ & $1.1(0.3)$ & 0.43 & $3.1(1.5)$ & $3.3(1.4)$ & 0.38 \\
\hline $\mathrm{HbA}_{1 \mathrm{c}}(\%)^{\mathrm{a}}$ & $7.9(1.1)$ & $7.0(0.5)$ & $8.3(0.6)$ & $<0.001$ & $6.8(0.6)$ & $8.7(1.0)$ & $<0.001$ \\
\hline Hypoglycaemic incidents in previous month, $n(\%)^{\mathrm{b}, \mathrm{c}}$ & $51(9)$ & $10(10)$ & $13(14)$ & 0.45 & $16(14)$ & $12(6)$ & 0.01 \\
\hline Clinical visits per year $(n)^{\mathrm{a}}$ & $4.0(1.8)$ & $4.1(1.6)$ & $4.0(1.4)$ & 0.59 & $3.9(1.5)$ & $4.1(2.1)$ & 0.22 \\
\hline Insulin dose (U/kg body weight) ${ }^{a}$ & $0.9(0.3)$ & $0.8(0.4)$ & $0.8(0.3)$ & 0.60 & $0.8(0.3)$ & $1.0(0.3)$ & $<0.001$ \\
\hline \multicolumn{8}{|l|}{ Insulin regimen ${ }^{\mathrm{b}}$} \\
\hline One to two injections per day, $n(\%)$ & $40(7)$ & $11(11)$ & $4(4)$ & & $7(6)$ & $4(2)$ & \\
\hline Three injections per day, $n(\%)$ & $84(16)$ & $20(20)$ & $27(30)$ & & $16(14)$ & $21(10)$ & \\
\hline Four or more injections per day, $n(\%)$ & $230(43)$ & $34(34)$ & $33(36)$ & & $60(53)$ & $103(49)$ & \\
\hline Insulin pump, $n(\%)$ & $184(34)$ & $36(36)$ & $27(30)$ & 0.16 & $30(27)$ & $84(40)$ & 0.03 \\
\hline BMI $\left(\mathrm{kg} / \mathrm{m}^{2}\right)^{\mathrm{a}}$ & $19.8(3.8)$ & $17.8(2.3)$ & $18.0(3.6)$ & 0.52 & $20.6(3.7)$ & $21.2(3.8)$ & 0.21 \\
\hline Overweight, $n(\%)^{\mathrm{b}}$ & $158(29)$ & $30(29)$ & $29(30)$ & 0.80 & $32(27)$ & $67(30)$ & 0.53 \\
\hline \multicolumn{8}{|l|}{ Mother's education, $n(\%)^{\mathrm{b}}$} \\
\hline Low ( $\leq 12$ years $)$ & $280(51)$ & $53(53)$ & $42(49)$ & 0.63 & $56(53)$ & $129(65)$ & 0.06 \\
\hline High (>12 years) & $210(38)$ & $47(47)$ & $43(51)$ & & $49(47)$ & $71(36)$ & \\
\hline \multicolumn{8}{|l|}{ Father's education, $n(\%)^{\mathrm{b}}$} \\
\hline Low ( $\leq 12$ years) & $284(52)$ & $54(57)$ & $52(62)$ & 0.49 & $58(56)$ & $120(63)$ & 0.25 \\
\hline High ( $>12$ years) & $188(34)$ & $41(43)$ & $32(38)$ & & $45(44)$ & $70(37)$ & \\
\hline
\end{tabular}

Values are mean (SD) or proportions $n(\%)$

${ }^{\text {a }}$ Two-sample $t$ test

${ }^{\mathrm{b}} \chi^{2}$ test

${ }^{\mathrm{c}}$ Hypoglycaemia needing help from other persons 
dose and body weight insulin per $\mathrm{kg}$ were missing for $30 \%$ of the participants and insulin per kg body weight was not included in the regression analysis.

All $p$ values are two-sided; a 5\% level of significance was used. All statistical analyses were performed with SPSS 14.0 (SPSS, Chicago, IL, USA).

\section{Results}

Characteristics of the participants are described in Table 1. Results are presented for those with optimal blood glucose control $\left(\mathrm{HbA}_{1 \mathrm{c}} \leq 7.5 \%\right)$ and those with suboptimal blood glucose control $\left(\mathrm{HbA}_{1 \mathrm{c}}>7.5 \%\right)$ in the two selected age groups (Table 1). The groups with low and high $\mathrm{HbA}_{1 \mathrm{c}}$ were in general comparable regarding age, pubertal development, weight, BMI, overweight, insulin regimens and parent's education. However, adolescents with poor glycaemic control had slightly longer diabetes duration, higher insulin dose, less hypoglycaemia and more pumpusers.

Optimal blood glucose control was associated with eating a recommended diet and not skipping meals. In adolescents, unadjusted regression analysis showed that low intake of added sugar, high intake of fibre, having breakfast and supper regularly, together with shorter diabetes duration and less intensive insulin regimen, significantly improved $\mathrm{HbA}_{1 \mathrm{c}}$ (crude values; Table 2). In the multiple regression model, high fibre intake, low BMI, having breakfast regularly, few clinical visits and short diabetes duration significantly improved $\mathrm{HbA}_{1 \mathrm{c}}$ (Table 2). In the multiple analyses in children, lower $\mathrm{HbA}_{1 \mathrm{c}}$ was significantly associated with low BMI and having dinner and supper regularly.

Table 3 shows details on intake of energy and macronutrients in the two age groups. Apart from intake of fat and fibre, which were higher and lower, respectively, than recommended, all intakes of macronutrients were adequate according to current recommendations [12]. Adolescents with optimal blood glucose control had a significantly lower intake of added sugar and significantly higher intake of fibre than adolescents with suboptimal blood glucose control. They also had a significantly lower intake of sugar-sweetened soft drinks and a higher total intake of fruits and vegetables. Among the children, no such significant differences were observed. Among the adolescents there were significantly more sugar-sweetened soft drink users among those with suboptimal blood glucose control than among those with optimal control $(38 \%$ vs $26 \%, p=0.03)$. This difference was not observed among the children $(31 \%$ vs $37 \%, p=0.33)$. No significant differences were found in the day-to-day variation (CV) of energy, carbohydrate, fibre and added sugar in relation to the $\mathrm{HbA}_{1 \mathrm{c}}$ groups (Table 3).

\section{Discussion}

This study shows that an irregular meal pattern is significantly associated with poor blood glucose control in Norwegian children and adolescents with type 1 diabetes mellitus, even though more than $90 \%$ were on intensive insulin treatment. In adolescents a low intake of fibre was also associated with high $\mathrm{HbA}_{1 \mathrm{c}}$. When looking at adolescents with optimal blood glucose control, they have a lower intake of added sugar and sugar-sweetened soft drinks, plus a higher intake of fruits and vegetables than those with suboptimal blood glucose control.

Blood glucose control was associated with having breakfast, dinner and supper regularly. The introduction of insulin via pump and multiple insulin injections has made the timing of meals more flexible for diabetic patients [28], possibly making some more prone to skipping meals. Frey et al. [29] found that better blood glucose control was associated with eating three meals a day among adolescents. Moreover, among Finnish diabetic adolescents a large number of meals per day was related to good blood glucose control and reflected a good coordination between insulin regimen and diet [1]. Our results suggest that avoiding the skipping of meals would help improve blood glucose control in children and adolescents.

An association between dietary fibre and $\mathrm{HbA}_{1 \mathrm{c}}$ was observed among the adolescents. This has previously been reported in one study among British adolescents from 1986 [11] and more recently among adults in EURODIAB [30], although not among north-western Europeans. The mechanism whereby increased fibre intake beneficially affects $\mathrm{HbA}_{1 \mathrm{c}}$ presumably relates to reduced postprandial blood glucose peaks. Thus, increased fibre intake may contribute to an overall improvement of glycaemic control [30]. The reason why this observation is only seen among adolescents could be because there are more adolescents than children in the present study and that the adolescents had a greater range of $\mathrm{HbA}_{1 \mathrm{c}}$, making dietary influence easier to detect. Mean intake of fibre and fruits and vegetables was lower than recommended (fibre $=40 \mathrm{~g} /$ day; fruits and vegetables $=$ $500 \mathrm{~g} /$ day $[12,31])$ for all groups regardless of age and $\mathrm{HbA}_{1 \mathrm{c}}$ in this study. However, among adolescents with optimal blood glucose control the intake was higher than in those with suboptimal blood glucose control.

As a group, adolescents with optimal blood glucose control had a lower intake of added sugar and sugarsweetened soft drinks and also fewer sugar-sweetened soft drink users than the group with suboptimal blood glucose control. Nutritional management of children with type 1 
Table 2 Crude and adjusted regression coefficients of explanatory variables for $\mathrm{HbA}_{1 \mathrm{c}}$ among the two age groups

\begin{tabular}{|c|c|c|c|c|c|c|c|c|}
\hline & \multicolumn{4}{|l|}{ 2- to 10 -year-olds } & \multicolumn{4}{|c|}{ 11- to 19 -year-olds } \\
\hline & \multicolumn{2}{|c|}{ Crude $(n=\max 203)$} & \multicolumn{2}{|c|}{ Adjusted $^{\mathrm{a}}(n=149)$} & \multicolumn{2}{|c|}{ Crude $(n=\max 347)$} & \multicolumn{2}{|c|}{ Adjusted $^{\mathrm{a}}(n=236)$} \\
\hline & Effect $(95 \% \mathrm{CI})$ & $p$ value & Effect $(95 \% \mathrm{CI})$ & $p$ value & Effect $(95 \% \mathrm{CI})$ & $p$ value & Effect $(95 \% \mathrm{CI})$ & $p$ value \\
\hline Sex & $\begin{array}{l}-0.16 \\
(-0.38,0.07)\end{array}$ & 0.18 & $\begin{array}{l}-0.17 \\
(-0.43,0.09)\end{array}$ & 0.20 & $\begin{array}{l}0.16 \\
(-0.10,0.42)\end{array}$ & 0.23 & $\begin{array}{l}0.11 \\
(-0.22,0.44)\end{array}$ & 0.51 \\
\hline Age (years) & $\begin{array}{l}-0.001 \\
(-0.06,0.05)\end{array}$ & 0.97 & $\begin{array}{l}0.008 \\
(-0.06,0.07)\end{array}$ & 0.81 & $\begin{array}{l}0.07 \\
(0.001,0.14)\end{array}$ & 0.05 & $\begin{array}{l}0.09 \\
(-0.01,0.19)\end{array}$ & 0.09 \\
\hline Diabetes duration (years) & $\begin{array}{l}-0.009 \\
(-0.07,0.05)\end{array}$ & 0.76 & $\begin{array}{l}0.04 \\
(-0.03,0.11)\end{array}$ & 0.27 & $\begin{array}{l}0.08 \\
(0.04,0.12)\end{array}$ & $<0.001$ & $\begin{array}{l}0.06 \\
(0.005,0.11)\end{array}$ & 0.03 \\
\hline Number of clinical visits & $\begin{array}{l}0.008 \\
(-0.07,0.08)\end{array}$ & 0.84 & $\begin{array}{l}0.04 \\
(-0.05,0.12)\end{array}$ & 0.39 & $\begin{array}{l}0.07 \\
(-0.002,0.14)\end{array}$ & 0.06 & $\begin{array}{l}0.08 \\
(0.001,0.15)\end{array}$ & 0.05 \\
\hline BMI $\left(\mathrm{kg} / \mathrm{m}^{2}\right)$ & $\begin{array}{l}0.034 \\
(-0.003,0.07)\end{array}$ & 0.08 & $\begin{array}{l}0.04 \\
(0.003,0.08)\end{array}$ & 0.04 & $\begin{array}{l}0.009 \\
(-0.03,0.04)\end{array}$ & 0.62 & $\begin{array}{l}-0.05 \\
(-0.10,-0.005)\end{array}$ & 0.03 \\
\hline Insulin regimen $^{\mathrm{b}}$ & $\begin{array}{l}-0.05 \\
(-0.17,0.06)\end{array}$ & 0.37 & $\begin{array}{l}-0.07 \\
(-0.20,0.06)\end{array}$ & 0.28 & $\begin{array}{l}0.21 \\
(0.03,0.39)\end{array}$ & 0.02 & $\begin{array}{l}0.13 \\
(-0.08,0.34)\end{array}$ & 0.23 \\
\hline Mothers' education $^{\mathrm{c}}$ & $\begin{array}{l}0.04 \\
(-0.20,0.28)\end{array}$ & 0.77 & $\begin{array}{l}0.11 \\
(-0.14,0.37)\end{array}$ & 0.38 & $\begin{array}{l}-0.18 \\
(-0.47,0.11)\end{array}$ & 0.22 & $\begin{array}{l}-0.14 \\
(-0.48,0.20)\end{array}$ & 0.41 \\
\hline Added sugar (E\%) & $\begin{array}{l}-0.013 \\
(-0.04,0.01)\end{array}$ & 0.32 & $\begin{array}{l}-0.012 \\
(-0.05,0.02)\end{array}$ & 0.48 & $\begin{array}{l}0.04 \\
(0.006,0.06)\end{array}$ & 0.02 & $\begin{array}{l}0.01 \\
(-0.03,0.05)\end{array}$ & 0.54 \\
\hline Fibre (g/day) & $\begin{array}{l}0.005 \\
(-0.02,0.03)\end{array}$ & 0.67 & $\begin{array}{l}-0.002 \\
(-0.03,0.02)\end{array}$ & 0.87 & $\begin{array}{l}-0.03 \\
(-0.05,-0.02)\end{array}$ & $<0.001$ & $\begin{array}{l}-0.022 \\
(-0.04,-0.001)\end{array}$ & 0.04 \\
\hline Breakfast $^{\mathrm{d}}$ & $\begin{array}{l}0.40 \\
(-0.42,1.22)\end{array}$ & 0.34 & $\begin{array}{l}-0.008 \\
(-0.92,0.90)\end{array}$ & 0.99 & $\begin{array}{l}-0.93 \\
(-1.48,-0.37)\end{array}$ & 0.001 & $\begin{array}{l}-0.89 \\
(-1.55,-0.22)\end{array}$ & 0.009 \\
\hline Dinner $^{\mathrm{d}}$ & $\begin{array}{l}-0.49 \\
(-1.04,0.06)\end{array}$ & 0.08 & $\begin{array}{l}-0.66 \\
(-1.23,-0.09)\end{array}$ & 0.02 & $\begin{array}{l}-0.47 \\
(-1.17,0.24)\end{array}$ & 0.20 & $\begin{array}{l}-0.30 \\
(-1.2,0.60)\end{array}$ & 0.50 \\
\hline Supper ${ }^{\mathrm{d}}$ & $\begin{array}{l}-0.36 \\
(-0.98,0.27)\end{array}$ & 0.26 & $\begin{array}{l}-0.78 \\
(-1.49,-0.08)\end{array}$ & 0.03 & $\begin{array}{l}-0.37 \\
(-0.73,0.00)\end{array}$ & 0.05 & $\begin{array}{l}-0.08 \\
(-0.54,0.34)\end{array}$ & 0.72 \\
\hline
\end{tabular}

$E \% \%$ of energy intake, max maximum

${ }^{a}$ Adjusted for all variables presented

${ }^{\mathrm{b}}$ Insulin regimen was divided into four: one to two injections per day, three injections per day, four or more injections per day and use of insulin pump

'Mothers' education was defined by $\leq 12$ or $>12$ years of education

${ }^{\mathrm{d}}$ Breakfast, dinner and supper are divided into those who had the meal six times per week or more and those who had the meal less than six times a week

diabetes mellitus has traditionally emphasised the exclusion of refined carbohydrate [32]. In the 1980s and 1990s several randomised controlled trials demonstrated that small amounts of sucrose in the diet had no adverse effects on blood glucose control in adults $[33,34]$ and children [32, 35], leading to a more liberal approach [12]. According to current recommendations, it is acceptable for patients with type 1 diabetes mellitus to have a moderate intake of free sugars if desired and if blood glucose levels are satisfactory [12]. From our results it seems that a lower intake of sugar and a lower consumption of sugar-sweetened soft drinks can make it easier to achieve optimal blood glucose control.

In our study, $\mathrm{HbA}_{1 \mathrm{c}}$ increased with increasing $\mathrm{BMI}$ in children, while the opposite was seen in adolescents, in whom $\mathrm{HbA}_{1 \mathrm{c}}$ decreased with increasing BMI. The latter has been reported earlier [7]. High BMI may indicate a too high dose of insulin; it has also been shown that increase in body weight may reduce insulin action [1,36], and this could explain our result among the children. Increased BMI is reported to be a side effect of intensive insulin treatment, explained by fear of hypoglycaemia that leads to overeating [37]. A high number of clinical visits in adolescents was associated with higher $\mathrm{HbA}_{1 \mathrm{c}}$, as has been described by others $[8,9]$. The result probably reflects the practice of following patients with poor control more closely. Furthermore, in adolescents $\mathrm{HbA}_{1 \mathrm{c}}$ increased with increasing diabetes duration, a finding that has been reported earlier $[2,6]$. This could reflect the decline or end of endogenous insulin production $[1,6]$ or the fact that $\mathrm{HbA}_{1 \mathrm{c}}$ often deteriorates with age in adolescents $[1,3]$.

In this study we used a food diary designed to be ideal for children and adolescents. This method captures much of the variability in food intake through extensive food lists and an open-ended approach [25]. The advantage of this method compared with those such as $24 \mathrm{~h}$ recall and dietary history is that intake is recorded as it is eaten, thus 
Table 3 Intake of energy and macronutrients and selected food items

\begin{tabular}{|c|c|c|c|c|c|c|}
\hline & \multicolumn{3}{|c|}{2 - to 10 -year-olds according to $\mathrm{HbA}_{1 \mathrm{c}}$} & \multicolumn{3}{|c|}{ 11- to 19 -year-olds according to $\mathrm{HbA}_{1 \mathrm{c}}$} \\
\hline & $\leq 7.5 \%(n=105)$ & $>7.5 \%(n=98)$ & $p$ value & $\leq 7.5 \%(n=121)$ & $>7.5 \%(n=226)$ & $p$ value \\
\hline Energy $(\mathrm{MJ})^{\mathrm{a}}$ & $7.4(1.7)$ & $7.4(1.8)$ & 0.86 & $8.7(2.2)$ & $8.5(2.7)$ & 0.51 \\
\hline Protein $(\mathrm{E} \%)^{\mathrm{a}}$ & $16.1(2.6)$ & $15.9(2.6)$ & 0.59 & $16.6(2.3)$ & $16.2(2.8)$ & 0.20 \\
\hline Carbohydrate $(\mathrm{E} \%)^{\mathrm{a}}$ & $48.8(5.9)$ & $49.1(5.7)$ & 0.72 & $48.5(5.5)$ & $49.1(5.8)$ & 0.37 \\
\hline Sugar $(\mathrm{E} \%)^{\mathrm{a}}$ & $8.1(4.1)$ & $7.8(4.5)$ & 0.60 & $7.7(4.1)$ & $9.1(4.7)$ & 0.004 \\
\hline Fat $(\mathrm{E} \%)^{\mathrm{a}}$ & $35.1(5.6)$ & $35.0(5.0)$ & 0.89 & $34.9(5.2)$ & $34.6(5.0)$ & 0.60 \\
\hline Fibre $(g / \text { day })^{a}$ & $15.3(4.9)$ & $15.7(5.4)$ & 0.56 & $19.3(9.0)$ & $17.0(7.1)$ & 0.01 \\
\hline White bread $(\mathrm{g} / \text { day })^{\mathrm{b}}$ & $11(0,30)$ & $0(0,30)$ & 0.19 & $11(0,38)$ & $19(0,53)$ & 0.12 \\
\hline Kneipp $(\mathrm{g} / \text { day })^{\mathrm{b}, \mathrm{c}}$ & $72(16,119)$ & $76(19,152)$ & 0.19 & $62(13,118)$ & $69(19,113)$ & 0.57 \\
\hline Wholemeal bread (g/day) ${ }^{\mathrm{b}}$ & $6(0,88)$ & $13(0,83)$ & 0.82 & $19(0,103)$ & $17(0,67)$ & 0.24 \\
\hline Yoghurt (g/day) $)^{\mathrm{b}}$ & $0(0,70)$ & $0(0,63)$ & 0.79 & $31(0,75)$ & $0(0,50)$ & 0.08 \\
\hline Soft drinks $(\mathrm{g} / \mathrm{day})^{\mathrm{b}, \mathrm{d}}$ & $0(0,38)$ & $0(0,23)$ & 0.53 & $0(0,16)$ & $0(0,75)$ & 0.01 \\
\hline Vegetables $(\mathrm{g} / \text { day })^{\mathrm{b}}$ & $45(21,90)$ & $43(17,77)$ & 0.60 & $67(40,104)$ & $51(25,91)$ & 0.01 \\
\hline Potatoes $(\mathrm{g} / \text { day })^{\mathrm{b}}$ & $26(8,53)$ & $35(16,58)$ & 0.05 & $53(18,93)$ & $43(18,79)$ & 0.07 \\
\hline Fruits $(\mathrm{g} / \text { day })^{\mathrm{b}}$ & $65(19,129)$ & $82(26,130)$ & 0.94 & $63(26,118)$ & $51(0,106)$ & 0.10 \\
\hline $\mathrm{FVJ}(\mathrm{g} / \text { day })^{\mathrm{b}, \mathrm{e}}$ & $193(115,299)$ & $196(118,276)$ & 0.82 & $257(174,400)$ & $227(139,353)$ & 0.04 \\
\hline \multicolumn{7}{|l|}{$\operatorname{CV}(\%)^{\mathrm{f}}$} \\
\hline Energy $^{a}$ & $21.9(14.6)$ & $25.6(13.1)$ & 0.058 & $27.5(13.7)$ & $28.3(13.7)$ & 0.58 \\
\hline Carbohydrate $^{\mathrm{a}}$ & $24.5(15.4)$ & $26.4(15.3)$ & 0.39 & $26.2(14.7)$ & $28.5(13.5)$ & 0.15 \\
\hline Added sugar ${ }^{\mathrm{a}}$ & $68.7(41.1)$ & $72.2(38.0)$ & 0.53 & $70.4(36.2)$ & $70.3(35.6)$ & 0.99 \\
\hline Fibre $^{\mathrm{a}}$ & $30.8(16.5)$ & $32.4(20.3)$ & 0.56 & $33.9(19.7)$ & $36.2(19.0)$ & 0.30 \\
\hline
\end{tabular}

Energy and macronutrients are mean (SD); selected food items median (Q1, Q3).

$E \% \%$ of energy intake

${ }^{\text {a }}$ Two-sample $t$ test

${ }^{\mathrm{b}}$ Mann-Whitney test

${ }^{\mathrm{c}}$ Kneipp is bread with less than $50 \%$ wholemeal flour

d Total intakes of sugar-sweetened soft drinks and lemonade

${ }^{\mathrm{e}} \mathrm{FVJ}$ is total intake of fruits, vegetables, potatoes and fruit juice

${ }^{\mathrm{f}} \mathrm{CV}$ in intake of energy, carbohydrate, added sugar and fibre

providing more accurate and more detailed information. Compared with weighed records it is also less timeconsuming for the participants and the researcher to conduct [38]. The present study is a population-based study of dietary intake and measurements of $\mathrm{HbA}_{1 \mathrm{c}}$ among children and adolescents with type 1 diabetes mellitus. Few studies have looked in detail at the relationship between dietary intake and blood glucose control in children and adolescents [1, 4, 10, 11, 39]. Most of these studies have smaller sample sizes than the present study. These previous studies $[1,4,10,11]$ have identified intake of fat [10, 39], saturated fat [4], fibre [1]) and day-to-day variations in energy intake $[1,10]$ to be related to $\mathrm{HbA}_{1 \mathrm{c}}$. However, fibre is the only factor replicated in this study. Among dietary factors, glycaemic index has also been studied, especially among adults [40], but also among children [41, 42], and was seen to have a rather small effect on blood glucose control in randomised control trials [40, $43,44]$.

Insulin regimen was included in the regression analysis, but was not a significant factor. Among those who had poorer glucose control there were more insulin pump users, possibly reflecting the fact that patients with blood glucose control are asked to use insulin pumps to help improve their blood glucose control. There were only minor differences in dietary intake between the two groups (data not shown) and the results were therefore not separated according to pump use. Insulin dose per kg body weight was only a significant factor in adolescents $(B=1.2[0.75,1.74], p<0.001)$, as reported by others $[7,8]$. Insulin dose per $\mathrm{kg}$ was higher among participants with suboptimal blood glucose control than among those with optimal blood glucose control, a finding that might reflect both the use of higher insulin dosage to achieve better control and the lower insulin sensitivity resulting from high blood glucose.

It could be argued that the clinical relevance of our results are scarce because of the small, albeit significant regression coefficients for some variables, However, it has been recognised that it is impossible to estimate the dietary intake of individuals without error and that the high random error associated with estimates of nutrient intake biases the correlation coefficients and slopes of regression lines 
toward zero [45]. Thus, the effect on $\mathrm{HbA}_{1 \mathrm{c}}$ of dietary intake is likely to be larger than estimated here.

It is important to notice some limitations of our study, which include the fact that dietary data were self-reported, which often results in under-reporting of energy intake [46]. According to Goldberg et al. [47], a ratio between energy intake and basal metabolic rate of less than 1.06 may indicate under-reporting. According to this, the total prevalence of under-reporting in our study was $20 \%, 28 \%$ among girls and $12 \%$ among boys. Many investigators have found that the most frequent under-estimated food items are 'unhealthy' ones such as sweets, desserts and snacks [48]. However, in a validation study of the food diary, the underreporters did not under-report unhealthy food to a greater extent than they did healthy food groups [25]. Another limitation of our study was the low response rate (34\%). A reason for the low response rate may be the considerable effort of detailed registration of food intake for 4 days. Of those who did not participate in the dietary study, $\mathrm{HbA}_{1 \mathrm{c}}$ and BMI were available from the NCDQ for 1009 participants. Among those who participated in the dietary study, $\mathrm{HbA}_{1 \mathrm{c}}$ was significantly lower $\left(\mathrm{HbA}_{1 \mathrm{c}}\right.$ mean difference $=0.24 \%$; $p<0.001)$ than among non-participants in analysis adjusted for age and sex, while there was no significant difference in BMI (BMI mean difference $=0.05 \mathrm{~kg} / \mathrm{m}^{2} ; p=0.77$ ). This could mean that our results are skewed in relation to $\mathrm{HbA}_{1 \mathrm{c}}$ and that they represent the part of the young diabetic population with good blood glucose control and diet. The reduced range in $\mathrm{HbA}_{1 \mathrm{c}}$ and dietary intake makes the regression analysis less sensitive. Furthermore, for more than $50 \%$ of the participants $\mathrm{HbA}_{1 \mathrm{c}}$ was measured before the diet was recorded. $\mathrm{HbA}_{1 \mathrm{c}}$ is a retrospective measurement for blood glucose control and so diet might not reflect the $\mathrm{HbA}_{1 \mathrm{c}}$ at time of recording. However, NCDQ data show that mean $\mathrm{HbA}_{1 \mathrm{c}}$ was stable over 3 years in this age group (data not shown) as is supported in the literature [49]. The median difference was 14 days, and we do not believe that much change in $\mathrm{HbA}_{1 \mathrm{c}}$ could have occurred during this time.

\section{Conclusion}

Optimal blood glucose control was associated with eating a recommended diet and not skipping meals. This is still important even when intensive insulin treatment with insulin pumps and multiple injections are used. Our results show that a regular meal pattern and high fibre intake are factors that improve $\mathrm{HbA}_{1 \mathrm{c}}$ in young diabetic patients. Among adolescents, moreover, lower intake of added sugar and sugar-sweetened soft drinks, as well as higher fruits and vegetables intake were observed among patients with optimal compared with suboptimal blood glucose control.
Our results support the policy that dietary guidance should be intensified during adolescence to improve dietary intake, meal pattern and blood glucose control.

Acknowledgements The authors would like to thank all the participants in the Norwegian Childhood Diabetes and Quality project. This project was financed with the aid of EXTRA funds from the Norwegian Foundation for Health and Rehabilitation.

Duality of interest The authors declare that there is no duality of interest associated with this manuscript.

\section{References}

1. Virtanen SM (1992) Metabolic control and diet in Finnish diabetic adolescents. Acta Paediatr 81:239-243

2. Rosilio M, Cotton JB, Wieliczko MC et al (1998) Factors associated with glycemic control. A cross-sectional nationwide study in 2,579 French children with type 1 diabetes. The French Pediatric Diabetes Group. Diabetes Care 21:1146-1153

3. Weissberg-Benchell J, Glasgow AM, Tynan WD, Wirtz P, Turek J, Ward J (1995) Adolescent diabetes management and mismanagement. Diabetes Care 18:77-82

4. Pietilainen KH, Virtanen SM, Rissanen A, Rita H, Maenpaa J (1995) Diet, obesity, and metabolic control in girls with insulin dependent diabetes mellitus. Arch Dis Child 73:398-402

5. Mortensen HB, Hougaard P (1997) Comparison of metabolic control in a cross-sectional study of 2,873 children and adolescents with IDDM from 18 countries. The Hvidore Study Group on Childhood Diabetes. Diabetes Care 20:714-720

6. Dorchy H, Roggemans MP, Willems D (1997) Glycated hemoglobin and related factors in diabetic children and adolescents under 18 years of age: a Belgian experience. Diabetes Care 20:2-6

7. Scottish Study Group for the Care of the Young Diabetic (2001) Factors influencing glycemic control in young people with type 1 diabetes in Scotland: a population-based study (DIABAUD2). Diabetes Care 24:239-244

8. Nordly S, Mortensen HB, Andreasen AH, Hermann N, Jorgensen T (2005) Factors associated with glycaemic outcome of childhood diabetes care in Denmark. Diabet Med 22:1566-1573

9. Urbach SL, LaFranchi S, Lambert L, Lapidus JA, Daneman D, Becker TM (2005) Predictors of glucose control in children and adolescents with type 1 diabetes mellitus. Pediatr Diabetes 6:69-74

10. Forsander G, Malmodin B, Eklund C, Persson B (2003) Relationship between dietary intake in children with diabetes mellitus type I, their management at diagnosis, social factors, anthropometry and glycaemic control. Scand J Nutr 47:75-84

11. Hackett AF, Court S, Mccowen C, Parkin JM (1986) Dietary survey of diabetics. Arch Dis Child 61:67-71

12. Mann JI, De Leeuw I, Hermansen K et al (2004) Evidence-based nutritional approaches to the treatment and prevention of diabetes mellitus. Nutr Metab Cardiovasc Dis 14:373-394

13. Dahl-Jorgensen K (1987) Near-normoglycemia and late diabetic complications. The Oslo Study. Acta Endocrinol Suppl (Copenh) 284:1-38

14. The Diabetes Control and Complications Trial Research Group (1993) The effect of intensive treatment of diabetes on the development and progression of long-term complications in insulin-dependent diabetes mellitus. The Diabetes Control and Complications Trial Research Group. N Engl J Med 329:977-986

15. Diabetes Control and Complications Trial Research Group (1994) Effect of intensive diabetes treatment on the development and 
progression of long-term complications in adolescents with insulin-dependent diabetes mellitus: Diabetes Control and Complications Trial. Diabetes Control and Complications Trial Research Group. J Pediatr 125:177-188

16. Larsen J, Brekke M, Sandvik L, Arnesen H, Hanssen KF, DahlJorgensen K (2002) Silent coronary atheromatosis in type 1 diabetic patients and its relation to long-term glycemic control. Diabetes 51:2637-2641

17. Nathan DM, Cleary PA, Backlund JY et al (2005) Intensive diabetes treatment and cardiovascular disease in patients with type 1 diabetes. N Engl J Med 353:2643-2653

18. Margeirsdottir HD, Larsen JR, Brunborg C, Dahl-Jørgensen K (2006) Nation-wide improvement in $\mathrm{HbA}_{1 \mathrm{c}}$ and complication screening in a Benchmarking project in childhood diabetes. A prospective national quality study. Pediatr Diabetes 7(Suppl 5): OP-4 (Abstract)

19. Overby NC, Flaaten V, Veierod MB et al (2007) Children and adolescents with type 1 diabetes eat a more atherosclerosis-prone diet than healthy control subjects. Diabetologia 50:307-316

20. Overby NC, Lillegaard IT, Johansson L, Andersen LF (2004) High intake of added sugar among Norwegian children and adolescents. Public Health Nutr 7:285-293

21. Cole TJ, Bellizzi MC, Flegal KM, Dietz WH (2000) Establishing a standard definition for child overweight and obesity worldwide: international survey. BMJ 320:1240-1243

22. Little RR, Rohlfing CL, Wiedmeyer HM, Myers GL, Sacks DB, Goldstein DE (2001) The national glycohemoglobin standardization program: a five-year progress report. Clin Chem 47:19851992

23. Swift PGF (2007) ISPAD guidelines 2000. Medforum, Zeist, The Netherlands

24. Lillegaard IT, Overby NC, Andersen LF (2005) Can children and adolescents use photographs of food to estimate portion sizes? Eur J Clin Nutr 59:611-617

25. Lillegaard IT, Andersen LF (2005) Validation of a pre-coded food diary with energy expenditure, comparison of under-reporters $\mathrm{v}$. acceptable reporters. Br J Nutr 94:998-1003

26. Lillegaard IT, Loken EB, Andersen LF (2007) Relative validation of a pre-coded food diary among children, under-reporting varies with reporting day and time of the day. Eur J Clin Nutr 61:61-68

27. Wolever TM, Hamad S, Chiasson JL et al (1999) Day-to-day consistency in amount and source of carbohydrate associated with improved blood glucose control in type 1 diabetes. J Am Coll Nutr 18:242-247

28. Sullivan-Bolyai S, Knafl K, Tamborlane W, Grey M (2004) Parents' reflections on managing their children's diabetes with insulin pumps. J Nurs Scholarsh 36:316-323

29. Frey MA, Ellis D, Naar-King S, Greger N (2004) Diabetes management in adolescents in poor metabolic control. Diabetes Educ 30:647-657

30. Buyken AE, Toeller M, Heitkamp G et al (1998) Relation of fibre intake to $\mathrm{HbA}_{1 \mathrm{c}}$ and the prevalence of severe ketoacidosis and severe hypoglycaemia. EURODIAB IDDM Complications Study Group. Diabetologia 41:882-890

31. Andersen LF, Overby N, Lillegaard IT (2004) Intake of fruit and vegetables among Norwegian children and adolescents. Tidsskr Nor Laegeforen 124:1396-1398

32. Loghmani E, Rickard K, Washburne L, Vandagriff J, Fineberg N, Golden M (1991) Glycemic response to sucrose-containing mixed meals in diets of children with insulin-dependent diabetes mellitus. J Pediatr 119:531-537
33. Slama G, Haardt MJ, Jean-Joseph P et al (1984) Sucrose taken during mixed meal has no additional hyperglycaemic action over isocaloric amounts of starch in well-controlled diabetics. Lancet $2: 122-125$

34. Bornet F, Haardt MJ, Costagliola D, Blayo A, Slama G (1985) Sucrose or honey at breakfast have no additional acute hyperglycaemic effect over an isoglucidic amount of bread in type 2 diabetic patients. Diabetologia 28:213-217

35. Schwingshandl J, Rippel S, Unterluggauer $M$, Borkenstein $M$ (1994) Effect of the introduction of dietary sucrose on metabolic control in children and adolescents with type I diabetes. Acta Diabetol 31:205-209

36. Yki-Jarvinen H, Koivisto VA (1986) Natural course of insulin resistance in type I diabetes. N Engl J Med 315:224-230

37. Craig ME, Handelsman P, Donaghue KC et al (2002) Predictors of glycaemic control and hypoglycaemia in children and adolescents with type 1 diabetes from NSW and the ACT. Med J Aust 177:235-238

38. Andersen LF, Pollestad ML, Jacobs DR Jr, Lovo A, Hustvedt BE (2005) Validation of a pre-coded food diary used among 13-yearolds: comparison of energy intake with energy expenditure. Public Health Nutr 8:1315-1321

39. Lodefalk M, Aman J (2006) Food habits, energy and nutrient intake in adolescents with Type 1 diabetes mellitus. Diabet Med 23:1225-1232

40. Brand-Miller J, Hayne S, Petocz P, Colagiuri S (2003) Lowglycemic index diets in the management of diabetes: a metaanalysis of randomized controlled trials. Diabetes Care 26:22612267

41. Gilbertson HR, Brand-Miller JC, Thorburn AW, Evans S, Chondros P, Werther GA (2001) The effect of flexible low glycemic index dietary advice versus measured carbohydrate exchange diets on glycemic control in children with type 1 diabetes. Diabetes Care 24:1137-1143

42. Mohammed NH, Wolever TM (2004) Effect of carbohydrate source on post-prandial blood glucose in subjects with type 1 diabetes treated with insulin lispro. Diabetes Res Clin Pract 65:29-35

43. Brand-Miller JC, Petocz P, Colagiuri S (2003) Meta-analysis of low-glycemic index diets in the management of diabetes: response to Franz. Diabetes Care 26:3363-3364

44. Gilbertson HR, Thorburn AW, Brand-Miller JC, Chondros P, Werther GA (2003) Effect of low-glycemic-index dietary advice on dietary quality and food choice in children with type 1 diabetes. Am J Clin Nutr 77:83-90

45. Beaton GH (1994) Approaches to analysis of dietary data: relationship between planned analyses and choice of methodology. Am J Clin Nutr 59:253S-261S

46. Black AE, Goldberg GR, Jebb SA, Livingstone MBE, Cole TJ, Prentice AM (1991) Critical evaluation of energy-intake data using fundamental principles of energy physiology. 2. Evaluating the results of published surveys. Eur J Clin Nutr 45:583-599

47. Goldberg GR, Black AE, Jebb SA et al (1991) Critical evaluation of energy-intake data using fundamental principles of energy physiology. 1. Derivation of cutoff limits to identify underrecording. Eur J Clin Nutr 45:569-581

48. Svendsen M, Tonstad S (2006) Accuracy of food intake reporting in obese subjects with metabolic risk factors. Br J Nutr 95:640-649

49. Jorde R, Sundsfjord J (2000) Intra-individual variability and longitudinal changes in glycaemic control in patients with type 1 diabetes mellitus. Diabet Med 17:451-456 